This item was submitted to Loughborough's Research Repository by the author.

Items in Figshare are protected by copyright, with all rights reserved, unless otherwise indicated.

\title{
From Teen Kanya to Arshinagar: feminist politics, Bengali high culture and the stardom of Aparna Sen
}

PLEASE CITE THE PUBLISHED VERSION

http://dx.doi.org/10.1080/19472498.2017.1304084

\section{PUBLISHER}

(c) Taylor \& Francis

\section{VERSION}

AM (Accepted Manuscript)

\section{PUBLISHER STATEMENT}

This work is made available according to the conditions of the Creative Commons Attribution-NonCommercialNoDerivatives 4.0 International (CC BY-NC-ND 4.0) licence. Full details of this licence are available at: https://creativecommons.org/licenses/by-nc-nd/4.0/

\section{LICENCE}

CC BY-NC-ND 4.0

\section{REPOSITORY RECORD}

Bakshi, Kaustav, and Rohit Dasgupta. 2019. "From Teen Kanya to Arshinagar: Feminist Politics, Bengali High Culture and the Stardom of Aparna Sen”. figshare. https://hdl.handle.net/2134/24578. 


\title{
From Teen Kanya to Arshinagar: feminist politics, Bengali high culture and the stardom of Aparna Sen
}

\author{
Kaustav Bakshi and Rohit K. Dasguptab \\ ${ }^{a}$ Department of English, Jadavpur University, West Bengal, India; ${ }^{\circ}$ nstitute for Media and Creative Industries, \\ Loughborough University, London, UK
}

\begin{abstract}
'his paper makes an attempt to understand the stardom of the Bengali film-maker and actor Aparna Sen, who has zen associated with the industry for 55 years. We argue that Sen's star persona is based on a polysemic structure, to borrow Richard Dyer's term, which comes from the multiple roles she has played in her career. Achieving a local stardom through her work as an actor in Bengali popular cinema, she went on to acquire international fame through the films she made. Besides, as the editor of an immensely popular Bengali women's magazine, Sen

became a cultural commentator through her columns and also played an active part, through the magazine, in sntering into dialogue with her readers on diverse issues such as communalism and sexuality rights. As a socially zonscientious critic who has participated in several humanitarian and political causes, Sen emerged as a figure of rust and reliance for her fans and even her staunchest critics. The paper analyses the construction of her stardom, based on a series of interviews that both authors con- ducted with Aparna Sen over a period of time, interviews with a cross section of her fans, alongside an analysis of her media presence and finally the films she made and acted in.
\end{abstract}

\section{¿YWORDS}

rarna Sen; female stardom; humanism; Bengali high culture; feminist Bengali films

\section{Introduction}

Aparna Sen is one of the most well-known auteur-actors in Bengali cinema, who has over the years emerged as a formidable star presence within the sociocultural milieu of not just West Bengal but also India. Sen started her career as an actor with Satyajit Ray's Teen Kanya in 1961 but then became a film-maker of international repute, though a little late in her career. ${ }^{1}$ Though most of the earlier films she acted in, being products of the mainstream Tollygunje-based Bengali film industry, did not have any mentionable access to the global film market, they, nonetheless, fetched her a local stardom and iconic status, which has still not waned.

Studies on Indian auteurs have proliferated in recent years, ${ }^{2}$ however, there have been few studies which have looked closely at the star text of the film-maker. Directors are rarely analysed as stars but more often as auteurs understood largely through the meanings of their oeuvre. A small number of directors in India do possess the visibility of stardom through the 'propensity for mythology' ${ }^{3}$ and most of these directors such as Guru Dutt and Raj Kapoor are actors turned directors. Aparna Sen is not only one of a very small group of female actors turned directors (others include Sai Paranjpye, Hema Malini, Pooja Bhatt, Nandita Das and Revathy ${ }^{4}$ ) but also the most well known. Sen is recognized not only for her direction and acting but also as a cultural and sociopolitical commentator. 
Writing about the era, in which Aparna Sen entered the film industry with an author-backed role in Satyajit Ray's Samapti (The Ending; a part of a collection of three films, Teen Kanya, 1961), Gooptu observes:

... the Left intellectual milieu of the 1960s and thereafter, gave rise to a discourse of the avant-garde wherein the cinema's primary potential lay in its ability to produce a radical political statement .... It produced a most drastic distinction between what was identified as "serious cinema" and the "commercial film" which catered for the box office ....

Aparna Sen straddled both worlds - she appeared in parallel/art films, while having a remarkable presence in the 'commercial' genre, in which she was often cast opposite the matinee idol Uttam Kumar. However, as Sen has repeatedly complained, she was never happy acting in commercial films, and given her exposure to world cinema and other avant-garde art forms, she was extremely critical of such films' clichéd plots, lack of innovation in form and content and melodramatic acting. In fact, her condescension for the commercial film earned her the tag 'snob' within the film industry. ${ }^{6}$ The first draft of her debut film as a director, 36 Chowringhee Lane (1981), Sen tells us, came into being in the make-up room of a Bombay studio, as she waited to be called for the next shot for one of those many commercial films she could not connect to intellectually: 'I began writing a short story out of exasperation. I asked myself whether I should continue to act in such films in which I did not believe'. ${ }^{7}$ Sen did not stop acting in these films, though. For, that earned her a livelihood. But she was creatively inclined to art-house cinema which, however, did not have as many viewers.

We argue that Sen's star persona is based on a polysemic structure, to borrow Dyer's term, which derives from the multiple positions that she has inhabited during her career. As mentioned earlier, she had already achieved local stardom through her appearance as an actor in Bengali popular cinema but it was through her directorial ventures that she became an international name. In addition, Sen was also the editor of Sananda, one of the most influential women's magazines in Bengali launched in 1986. In the capacity of an editor, she became a cultural commentator through her columns and also played an active part, through the magazine's forum, in entering into dialogue with her readers on issues such as communalism and sexuality rights, alongside home remedies and cooking tips. This role became further cemented when she started appearing on various television shows both as host (for example, Aparna Online on Kolkata TV) and a guest allowing her a greater visibility and closeness to her fans. Finally, through being as a socially conscientious critic who has participated in several humanitarian and political causes, ${ }^{8}$ she remained a figure of trust and reliance for her fans and even her staunchest critics.

Dyer writes that a star image is 'a complex configuration of visual, verbal and aural signs [that] function crucially in relation to contradictions within and between ideologies which they seek variously to manage or resolve'. ${ }^{9}$ Marshall argues that stardom and celebrity culture comprise an active construction of identity in the social world and through the blurring of boundaries between the private and the public, the idea of an 'authentic individual' cements one's stardom. ${ }^{10}$ Following on from Dyer and Marshall, Sen's presence as an actor and director and her activities and involvements off-screen played a crucial role in bringing together the star. Dudrah et al argue that such processes are on the one hand linked to the personal life of the star (in Sen's case, her upbringing, her relationships, her political activism), and, on the other, to their various roles onscreen (the films she acted in and the characters she created in her own films). ${ }^{11}$ The structured polysemy of Sen's stardom can be understood to embody the multiplicity of meanings generated through her performance as an actor, film-maker, journalist, cultural commentator and politically conscious public persona.

This article is based on a series of interviews that both authors conducted with Sen over a period of time, interviews with a cross section of her fans, alongside an analysis of her media presence (in interviews, editorials, articles) and finally her films. We begin the article by 
contextualizing Sen's stardom and locating her within the Bengali film industry milieu that she has been a part of for 55 years. This is followed by close analyses of the films she has directed and acted in since she began as Ray's Mrinmoyee in 1961.

\section{The 'responsible' star persona}

In 2003, Coke and PepsiCo, the country's two top and eternally warring soft drink companies were faced with a terrible crisis when their products were deemed to contain a perilous amount of pesticides. Both the companies, anxious of sustaining a heavy loss, were desperate to recuperate people's faith in them. ${ }^{12}$ Their marketing strategy then was to engage reliable public icons in their advertisement campaigns, particularly those who were respected for their serious involvement with public affairs. Aamir Khan was signed on by Coke, while Sachin Tendulkar who was already a PepsiCo brand ambassador promoted the company's claim that Pepsi was absolutely safe. In Eastern India, Coke approached Aparna Sen to join the campaign of reinstating people's confidence in the brand, because Sen's stardom, her political consciousness and close engagement with social issues were expected to have a tremendous bearing on Coke's Eastern India's target consumers. But, Sen refused to sign the contract, although they offered her an astronomical signing amount. Deeply distressed by the plight of farmers brought about by a Coke plant in Palakkad, Kerala, she did not think it was ethically correct to join the campaign. Sen's turning down of the offer was never publicized in the media nor did she speak about it in public. However, as she told us, what she instantly knew, when approached by Coke, was that she would irrevocably lose her credibility as a socially responsible media personality whom her audience looked up to, had she agreed to their offer. ${ }^{13}$

Contextualizing Sen's rejection of the Coke offer helps usher one into understanding her star persona - radical, humane and socially responsible - an image she went on cultivating and preserving for years. Coke was keen to harness the very same persona in their project of reconstructing their own image as a trustworthy brand. The paradox of the situation was that it would have sullied Sen's own image completely had she agreed to be part of the campaign. Star power is often determined by an actor's 'commercial value' often gauged in terms of the brands he or she endorses or promotes. Coke's approaching Sen at the time of a huge moral and economic crisis they encountered spoke volumes about her star power; but Sen did not allow herself be manoeuvred into complying with the aggressive capitalist machinery of star production in which younger stars were willing participants. As opposed to Aamir Khan, or Sachin Tendulkar, Sen was way past her prime when this offer came to her; in fact, she was almost 60. Her stardom was already firmly established in a certain vein, and not only did she not need endorsements to reinforce it, she would have also seriously compromised her public image which had been constructed over the years. Sen was certainly aware of this, and ironically, by rejecting the offer to endorse a global brand, she actually kept her image inviolate. When Sen turned down the offer, Aamir Khan stepped in, in the role of a traditional Bengali babu, in Coke's campaign in Eastern India.

However, this image of a 'responsible' and socially aware star received a serious blow when Sen was summoned by the Enforcement Directorate for her association with the Saradha group scam ${ }^{14}$ which left thousands of investors destitute. Sen was the editor of a women's magazine run by the Saradha group. In an interview with the English news channel NDTV, Sen defended herself, denying any ideological association with the ruling party, Trinamul Congress, several ministers of which were implicated in the scam. In her defence, Sen played up her image of a socially responsible citizen, who would not have gotten herself involved with Saradha had she known how it functioned. Emphasizing the fact that she was only a 'salaried employee' of Saradha and no monetary transaction ever took place through her, Sen averred: 'Everyone knows that my politics is issue-based. In fact, after the Kamduni affair ${ }^{15}$ I protested against the Trinamul government at College Square in Calcutta. Our magazine carried some critical articles'. When asked by the 
interviewer, why she carried on with the company even after discovering it was part of a Ponzy scheme, Sen came up with an interesting answer: she could not quit for her quitting would lay off other employees, of which two were a couple. In the face of accusations levelled at her, Sen managed to project her humaneness. She rounded up the interview with the confession that she regretted joining Saradha Printing and Publications. ${ }^{16}$

The production of stardom is inextricably twined with commodity cultures. As Walter Benjamin observes, "The cult of the movie star fostered by the money of the movie industry preserves not the unique aura of the person but the "spell of the personality", the phoney spell of the commodity'. ${ }^{17}$ Aparna Sen's stardom constructed through the numerous films she acted in or directed was certainly never outside, to use a phrase from Lisa Taylor, the "political economy" ${ }^{\text {' }}$ of star production. But the incidents narrated above can still be used as entry points in understanding the uniqueness of Sen's stardom. By repudiating Coke's offer, Sen, as she told us, prioritized a larger social cause she believed in over her personal gains. As a defence against her involvement with the Saradha group, she harped constantly on a humanitarian ground for not quitting the company, besides highlighting on her persistent critique of the government, with which she was alleged to be involved via Saradha. These incidents, however, could not be understood meaningfully in isolation. Both these incidents, actually, present interesting examples of a star's conscious or unconscious attempts at protecting and perpetuating an image which has been established over the years - her cultural and intellectual legacy, in the films she made and the political and cultural discourses she engaged with in them.

\section{Aparna Sen's global Bengaliness: high art and socialist humanism}

I

Aparna Sen has carried forward a legacy of Bengali high art, of which cinema was a late addition. In several interviews, Sen proudly harps on the fact that she was brought up on a diet of films completely different from the kind she mostly acted in. In fact, at home, there was strict interdiction on watching mainstream Bengali or Hindi cinema. This different diet included world cinema the Calcutta Film Society, founded by her father Chidananda Dasgupta and Satyajit Ray, showcased. These films, which were scarcely known to the average Bengali moviegoer of those times, brought together a gamut of Calcutta intellectuals, many of whom became filmmakers later on. At one point, the Film Society meetings were often held in a room in Dasgupta's house, when, the cinema of Eisenstein, Carl Th. Dreyer, Pudovkin, Robert Flaherty, John Grierson, Marcel Carne, Julien Duvivier, Akira Kurosawa and such others was animatedly discussed. As she grew up, besides world cinema, Sen was exposed to a wide range of world literature: while on the one hand she was introduced to Bengali classics, Bankim Chandra Chattopadhyay and Rabindranath Tagore, along with other more contemporary Bengali writers, she also voraciously read English and European classics. Simultaneously, she was trained to develop an admiring ear for western classical music, apart from its Indian counterpart. In an interview with Ranjan Ghosh, Sen's co-writer in the film Iti Mrinalini (2011), ${ }^{19}$ she says:

See, we had a great exposure to both Indian and western classical music. Baba [her father, Chidananda Dasgupta] was a great admirer of Mozart. We grew up listening to Mozart playing in our house. I can identify the Horn Concerto just by listening to a few seconds of it .... I listen to a lot of instrumental music. Hugely admire sitarist Nikhil Bandopadhyay. One of my favourite singers was Ustad Amir Khan. But that was long ago.... I admire the late Pandit Bhimsen Joshi, then Ustad Rashid Khan. And, of course, Rabindrasangeet, since childhood $\ldots^{20}{ }^{20}$

A lively cultural environment prevailed in the home Sen and her sisters grew up in. Apart from future film-makers, well-known writers, among them Kamal Kumar Majumdar, Buddhadeb Bose, Jibananda Das, who was also Sen's mother's first cousin, and other stalwarts, often visited the Dasgupta household and engaged in highly productive addas to which the children had 
unrestricted access. Sen recalls, with a sense of gratitude, that these addas, in which literature, cinema, theatre, world politics and other burning issues of the times were conferred on, had been most influential in shaping her world view. Later, when she joined Presidency College, Sen developed a strong leftist vision, aided not only by the kind of films she watched or the people she came in contact with at home but also through socialisation with left radicals, the college being the hotbed of Naxalite politics at that time. She briefly touched upon this milieu in Iti Mrinalini, in which the protagonist, partially modelled on her, falls in love with a Naxalite while studying at Presidency. The turbulent political milieu of the 1970s was again shown in her film Goynar Baksho. Explaining how the jewellery box travelled from being blocked capital to fluid capital to a resource for funding the Bangladesh Liberation War of 1971, Sen told film-maker Rituparno Ghosh:

A very important element in Goynar Baksho is the journey of the jewellery box. The jewellery, for Pishima, is hoarded or blocked capital. For Somlata, it becomes capital. When it comes to Chaitali, times have changed even more. She's a modern girl of the Seventies with Leftist ideals ... tokhon jamon hoto, like we all were .... $^{21}$

Satyajit Ray and Chidananda Dasgupta, besides being colleagues at the same advertisement firm, shared another commonality - both belonged to the Brahmo Samaj. ${ }^{22}$ They, together with other elite Bengalis, represented a bhadrolok class in post-independence Calcutta, which carried forward the legacy of a Bengali high culture. There was a strong urgency, among this group, deeply rooted in leftist ideals, to constitute a Bengaliness, a cultural difference, even superiority, which was increasingly waning in the post-independence, post-Partition years. Sharmistha Gooptu attributes this sense of disenchantment of Bengalis to 'refugee crisis, growing unemployment and chronic food shortage ${ }^{23}$ that plagued late colonial and postcolonial Bengal. She writes that the history of the 1940 s suggests that

\footnotetext{
during these years the Bengali bhadrolok - who had originally constituted the nationalist movement increasingly lost their sense of being historical agents, something they had inherited from the so-called "renaissance" that took place in Bengal in the nineteenth century .... A dystopic vision therefore is commonly believed to have become central to the Bengali imaginary, which climaxed in the middle class youth's turn to a radical politics in the $1960 \mathrm{~s}^{\prime} .^{24}$
}

While reconstruction of a unique Bengaliness was also a project which mainstream Bengali cinema took upon itself, the Calcutta intelligentsia, wished to recoup Bengal's intellectual and cultural pre-eminence by adapting the Euro-American avant-garde to represent Bengal. They were in line with the Bengal renaissance thinkers who successfully merged Sanskritic and other nonEuropean traditions with modernist-rationalist ideas derived from the West. Cinema, which was a product of modernity, also demanded 'a style, an idiom, a sort of iconography of cinema, which would be uniquely and recognisably Indian'. ${ }^{25}$ Pather Panchali/Song of the Little Road (1955), which Dasgupta thought was the Bengali film he could take his daughters to watch, ${ }^{26}$ is believed to have introduced that idiom, exclusively Indian, but global and universal in appeal. Dasgupta, in his assessment of the film, proudly underlines its artistic disavowal of the existing Bengali cinema: '... neither in content nor in style did Ray's films owe anything at all to Bengali, indeed Indian cinema traditions' ${ }^{27}$ In the process, it was argued that Ray inaugurated another cinematic tradition, combining the modern with the traditional, the global with the local - which Sen drew from. Sen admits:

It was very difficult not to be influenced by [Ray] in the same way that writers were influenced by Tagore. At that time, he was like a huge banyan tree. We had come from the same kind of background - enlightened liberal Brahmo stock. $^{28}$

In early assessments of Ray's films, humanism has often been invoked - 'as a matter of being both humane and democratic, of embracing non-melodramatic celebration of common life, openness of form, multiplicity of interpretation. It was also a matter of commitment of 
scientific spirit, to a notion of progress, and to the centrality of individual conscience' ${ }^{29}$ The humanism of Ray, as Dasgupta observes, had its roots in the Upanishads and Tagore's writings - an antithesis of Western humanism that assumes an anthropocentric universe, celebrating man's supremacy and undeterred progress. ${ }^{30}$ Aparna Sen also persistently emphasizes her 'humanism', at times, subsuming her feminist politics within a larger humanist compassion for the oppressed and marginalized. While there is a deep consciousness of the individual's insignificance in the vast cosmic order, there is also a great faith in the individual's ability to combat social forces that thwart their evolution, notwithstanding their tragic predicament. Speaking about Violet Stoneham, the protagonist of 36 Chowringhee Lane (1981), her first directorial venture, Sen reminisces:

Miss Stoneham was supposed to go away to Australia in 36 Chowringhee Lane ... but I just couldn't make her go! Sometimes the characters you have created start taking their own decisions. And that is a very organic process. You know, reaffirmation of life is a natural instinct with me. Maybe because of my Brahmo upbringing, the Upanishads .... ${ }^{31}$

Almost as a continuation of this thought, in the same interview, she recalls how Tagore's Bipultarango $\mathrm{re}^{32}$ came to her automatically while scripting the death scene of Sanaka at the end of Paromita'r Ekdin/House of Memories (2000). Although she does not elaborate on the immense effect the song had on the cinematic composition of the scene, it is not difficult to see how it worked: the evanescence and eternal return of life Tagore speaks of in the song, the instance of Sanaka's death, Khuku's desolation and the excitement of the arrival of a new life - all converge into an organic whole, lifting that particular moment from its temporality to an elusive cosmic infinity. This is a unique cinematic idiom, localized in Bengali high culture, yet, intelligible to a global audience, which Sen creates, in the footsteps of her mentors - Tagore and Ray. This is also one of the ways in which Sen has preserved in her cinema the tradition of a quintessential Bengali high art, while interpolating it with individual questions and soul-searching. Sen, as evident from her interviews, is often celebratory of her background and the artistic influences on her work. Her high-brow dismissal of popular cinema is one instance of her immense pride in this elitist upbringing.

\section{II}

However, Sen's stardom among the Bengali intelligentsia rests not only on carrying forward a high cultural legacy of Bengali art. Sen has traversed more radical paths, than, say, Ray. In her radicalism she broke rather humongous taboos surrounding female sexuality. Paroma/The Ultimate Woman (1984) is a case in point. Paroma is the story of a Bengali woman (played by Rakhee Gulzar) whose well-settled and predictable family life is threatened by the arrival of Rahul (Mukul Sharma), a photojournalist with whom she has an extramarital affair. This affair leads to discord and breakdown of Paroma's family life but in the process also leads her to go through a mode of self-discovery and break out of her socially ascribed gendered role(s). The film, which was much ahead of its time, raised extremely valid but disturbing (especially for the bhadralok middle classes) questions about a woman's right over her body and sexuality.

Sen's films have always frequently shaken the Bengali middle class out of their complacence, not only by naturalizing sexual desires and uninhibited representation of coital intimacy onscreen but also by weaving their narratives around images of war, terrorist and communal violence, and concerns for environmental degradation, one of the biggest banes of modernity subjects which are not so frequently spoken of at the middle-class dining table. Each of these films constantly returns to the peripheries of society, turning the search lights on the underprivileged, the marginalized. Although Sen has never exhibited a deep proletariat consciousness, the underprivileged in her films often take the forms of ethnic minorities, ageing and specially abled individuals, and of course, women, still embodying a subalternity within hetero-patriarchal 
structures. In this section, we discuss some of her very well-received films to bring home the humanitarian as well as radical drift of her art.

The plight of a fast depleting Anglo-Indian community in postcolonial Calcutta is the subject of 36 Chowringhee Lane, her critically acclaimed directorial debut. Bengali film-makers rarely ever thought of turning to this community, which, in any case, was not looked upon with sympathy by Indians soaked in ethnonationalist sentiments post-independence. ${ }^{33}$ The film shows a lonely and ageing Anglo-Indian school teacher Miss Violet Stoneham's everyday life in a dingy apartment, which takes a temporarily delightful turn when a younger unmarried couple befriends her, though only to make use of her place to spend some intimate moments. Sen captures a liminal cultural space within a Bengali-dominated city in this English language film, underlining that a reverse colonisation that has taken place, whereby the Anglo-Indians are sufficiently marginalized. A politically turbulent postcolonial city haunts the periphery of this quotidian world of AngloIndian men and women suddenly faced with the challenge to cope with the changing realities of disempowerment and a deep sense of loss. The withered tone of the film's visual texture underscores not only the isolation of the community but also the idea of a residual culture that could never be completely eliminated years after the independence. Miss Stoneham's exploitation, on the other hand, by the younger Bengali couple becomes symbolic of a moral degeneration, purported by an aggressive capitalist economy: human relations are preserved as long as they have a function.

Sen has often collapsed the secure boundaries of the middle-class living room, forcing it out of its general indifference to the political world outside. One instance could be the violent stills of the devastating Lebanon War of 1982, which enters Paroma's upper-class family room through Rahul. The family which gathers to view the photographs of Durga Puja is disconcerted by the pictures of the bombing in Beirut - by juxtaposing the appalling violence of the Lebanon War with the congeniality symbolized by the Durga Puja, Sen briefly robs a Bengali household's sense of security, when the 'safe' geographical distance between Lebanon and Calcutta is suddenly erased. Incidentally, this moment also anticipates for Paroma the possibility of stepping across the sacred and supposedly inviolable line of virtue dividing the safety of the home and an adventurous world.

Yugant (What the Sea Said, 1995) expands the horizon of the Bengali middle class infinitely in locating the problems of a separated couple against the backdrop of the Gulf War of the early 1990s. The Gulf War was not really a distant reality as the Lebanon War might have been for Bengalis. Given the emergence of satellite television networks, disturbing pictures of the war entered the Bengali living room every day, making its reality a more immediate one. Participating in discourses of globalisation, of American imperialism, Yugant, as Sayandeb Chowdhury observes is unique in its 'prophetic exposition of the idea of the Anthropocene, to which the sciences and critical humanities disciplines have only recently turned' ${ }^{34}$ Chowdhury places the film in the same category with Theo Angelopoulos's haunting epic Ulysses' Gaze (1995), and other international films such as The Truman Show, (Dir. Peter Weir, 1998), Ermo (Dir. Zhou Xiaowen, 1994) and Underground (Dir. Emir Kusturica, 1995). Sen's films, therefore, while being located within Bengali middle-class households, also inhabit a transnational space, without actually crossing the borders.

The same is true of Sen's much acclaimed Mr. E Mrs. Iyer (2002). Based on an imaginary communal riot 'somewhere' in India, the film locates itself within a global discourse of violence and terrorism: the film begins with a montage of newspaper headlines ('Gunmen open fire on a Thai school bus', 'Maoists go on a killing spree in Nepal again', 'Carnage in Karachi', 'Suicide attack in Jammu', etc.) and mixed voice-overs from television news highlighting the ubiquity of ethnic violence across the globe, the event in the film being only one out of many. These distressing images and news reports dissolve into four lines from the tenth-century Indian poet, Devara Desimayya: 'For what shall I wield a dagger, o lord?/What can I pluck it out of/Or plunge it into/When you are all the world?' The philosophy in these lines is also upheld by the film, 
ending on the possibilities of forging meaningful humane bonds across ethnic or religious differences.

Firmly located within recognisable political milieus, these films throb with humanistic compassion and altruism, which Sen claims to be the essence of her art. With such a legacy of films behind her, Aparna Sen emerged as a star film-maker who found national and global recognition quite readily. Her humanistic concerns for people killed in war, victims of ethnic violence, degeneration of the environment caused by war, found manifestation not only in her films but also in the editorials she wrote for the Bengali women's magazine Sananda launched in 1986, after the stupendous success of Paroma. ${ }^{35}$ Flipping through random issues of the magazine, one is struck by Sen's editorials and other articles which compulsively and engagingly dealt with social and political issues, current at that time - issues which one does not expect to come across in a highly consumerist magazine. Although Sen drew criticism for compromising with her leftist brand of politics in consenting to edit such a magazine, ${ }^{36}$ the editorials, articulating thoughtful opinions and scrupulous post-mortems of sociopolitical realities, projected a different Aparna Sen inhabiting a world beyond the comforts of aesthetically furnished living rooms, goodies-stacked modular kitchens and upscale sari stores. For instance, in several issues following the Babri Mosque riots in December, 1992, Aparna Sen relentlessly condemned militant nationalism, vociferously protesting against erecting communal borders in a secular nation. These editorials, in fact, when read now, appear to be preparing grounds for Sen's Mr. E Mrs. Iyer. The 15 January 1999 issue is of immense significance for the cover story entitled 'The Heat of Fire' which examined the radicalism of the Deepa Mehta film Fire in terms of its depiction of female sexuality, while disparaging the Shiv Sena for ransacking the theatres where the film was showing. While Fire officially brought out female same-sex desire in the Indian discourse, Sananda, true to its ideologies of women's liberation, introduced its readers to expert commentary on the film, thereby taking a very important step towards accommodating lesbianism in the consciousness of its less informed readers. Editorials commented on other burning issues of the time, often betraying the author's left liberal standpoint. We conducted a small survey of how Sananda influenced everyday lives of its avid readers. Shakuntala Sinha, a Kolkata-based 45-year-old homemaker and a long-time reader of Sananda reminisces"

When I first got married and started living with my in-laws, I hardly knew anything about how to run a home. Sananda was a guide to everything I needed to be aware of- from how to make dhania chicken to learning about state politics. I was also very interested in reading the advice columns, which was an eye opener for me to know about how complex families can be. I had never heard the word somokami (homosexual) until $\mathrm{I}$ read it in that magazine for the first time. ${ }^{37}$

Similarly, Sumit, 32, a PhD scholar at a top Indian university who identifies as gay, observed:

Well, I encountered Sananda during my pre-adolescent days, sometime in the early 1990s ... 'sexuality', as I look back now, was a taboo within the family .... It was thanks to Sananda that I was enlightened about these 'taboos' (as were considered by my somewhat conservative family elders) like conjugal issues, divorce, abortion, single motherhood, living together, the cultural significance of sexuality in general, fashion and make-up, interior decoration of 'good taste and high class' and so on. As I look back now, Sananda helped me grow mature and I am not flattering even a bit. While my cousins and other peers would read Anandamela[a Bengali magazine for teens and young adults] and enjoy their young adulthood and consider anything to do with sex and sexuality as 'hush hush' matters to giggle about, in the absence of elders, I would think through 'issues' deliberated upon in Sananda. ${ }^{38}$

Chhabi Nag, 63, a housewife from a small town in West Bengal told us:

Sananda opened up for us, homemakers, a whole new world we were not conscious about at all. We got to know a lot about women's liberation, got new perspective on everyday affairs of the household, and developed a modern vision of life. ${ }^{39}$

Sonalika Ghosh, 39, an IT professional, who grew up in a remote village in Bengal, had found Sananda similarly illuminating: 
Sananda had an important role in propelling the women's liberation movement in Bengal forward. This magazine actually introduced a new genre of popular literature: combining politics, education and lifestyle issues, it constructed the image of the modern 'complete woman'. There was barely anything like this before. $^{40}$

These views taken from a cross section of the readers of Sananda reveal that one role which this popular magazine definitively and successfully played was in educating both men and women about sexuality and ideas of gender equality. Sen's editorials were bold, often political, and showed her strong acumen in understanding the changing society around her, but it was her perception of ethics and honesty that made her exceptional. It is this image which Coke had wanted to capitalize, when they needed to reinstate people's trust in the brand. Her decision to return Coke's offer or her means of self-defence when confronted with charges of being involved with the Saradha scam is in conformation with this public image - the one analysed above - of a socialist, humanist artist, who would not compromise with her own beliefs.

\section{Feminist sensibilities, auteurism and stardom}

Aparna Sen became a film-maker with 36 Chowringhee Lane, which was a part of the emergence of what is called the 'middle cinema' in India. ${ }^{41}$ Although she is self-critical of her performance in mainstream cinema, Sen's unique ability to balance the commercial with the avant-garde that

fetched her immense popularity among the more liberal sections of the Bengali bhadrolok. Sen's

'middle cinema' addressed mainstream audiences but also sought to make political statements on issues such as women's rights, ageing, physical and mental disabilities, environment and changing social structures. In attempting to understand Sen's feminist politics (even though she calls herself a humanist), we examine two of her most celebrated films - 36 Chowringhee Lane and Paroma. 36

Chowringhee Lane was released at a time when there were no female film-makers to reckon with within an industry that mostly ran on cheap copies of Bombay films. Narayanan writing about 36 Chowringhee Lane argues that Sen, telling the story of a postcolonial Anglo-Indian community through the narrative of an ageing female protagonist in an era which privileged 'upper-class young things falling in love', cemented the film's entry into the canon of serious Indian cinema ${ }^{42}$ Though Violet Stoneham (played by Jennifer Kendal) does not self-identify as a feminist and neither does Sen give into the didactic temptation of calling her one, the adroit deployment of the female identity and sensibility of the character to make sense of postcolonial Calcutta through the eyes of a single ageing woman foregrounds Sen's nascent feminist politics. The specificity of the mailing address evokes the connection between feminist politics to space. In fact Narayanan compares the film to Chantal Akerman's brilliant 1975 film exploring a middleaged widow's life - Jeanne Dielman, 23 Quai Du Commerce, 1080 Bruxelles. Feminist geographers such as Staheli and Martin have argued that spatial metaphors are used to draw an idea of space as something that is familiar where the flow of capital and kinship provokes strong responses of belonging and subversion. ${ }^{43}$ Thus, spaces such as the chhader-ghar (room on the roof) or the terrace in joint Bengali households become a place of world-making for Bengali women. ${ }^{44}$

The title sequence of Violet dozing off on a rickshaw after a long day of teaching, travelling through the narrow streets and lanes of Calcutta only to be confronted by an 'out of order' sign on her lift against the sad, discordant title score (composed by Vanraj Bhatia and performed by the CMA orchestra) signals the isolation and dull existence of Violet. As audiences, we are confronted with her immense loneliness on discovering that her sole companion is Sir Toby Belch, a cat and the memories of her lover Davy who died during the Second World War.

At this juncture, Sen introduces us to Nandita (played by Debashree Roy) and her lover Samaresh (Dhritiman Chatterjee) who enter Violet's life, assuming identities of innocent friends wanting a quiet place to write and appeal to Violet's need for companionship. Violet agrees to lend them her place. Unknown to Violet, she is taken advantage of and the very personal space of her home is taken over by the two lovers for long afternoons of making love. Space and its role in 
the constitution of subjectivity are important to understand why this betrayal of Violet's trust and her letting go of her personal space is central to the film. In foregrounding the importance of the personal female space, Sen leads her audience to confront the connection between this betrayal from a loved one and the tragedy of giving up one's personal space. Nandita and Samaresh's lovemaking deepens Violet's own sadness at not being married and of losing Davy so early in life. Sen deploys a fantastic dream sequence to show a young Violet getting married to Davy in a cemetery and the bridegroom entering the coffin as soon as the marriage ceremony ends. This uncanny and distressful scene intensifies the sadness of Violet's lonely life as an ageing single woman. Sen parallels Violet's situation, which keeps getting worse (after a new principal forces several Anglo-Indian teachers to leave) with Nandita and Samaresh's improving lives. Samaresh gets employment and soon they are married. Violet, a conspicuous presence in the wedding photographs, soon turns out to be an avoidable nuisance in Nandita and Samaresh's life in the new house among newly acquired younger friends. By contrasting this conjugal bliss against Violet's own lonely existence and repressed sexuality, Sen in subtle ways also critiques the assumed centrality of normative marriage. The intertextual reference to King Lear when the film ends with Violet reciting some of the memorable lines from the play also evokes how like the character of King Lear, Violet too is shunned and driven away by her own kith and kin. Sen's interest in the figure of the 'lonely woman' carries on into her next film Paroma where her exploration of female sexuality and feminist politics becomes much more pronounced.

Paroma opens in the courtyard of an affluent Bengali family, celebrating Durga Puja, with a busy Paroma managing the household, looking after the puja proceedings, addressing everybody's needs and taking time out to hand over her ageing mother-in-law her medicines. While Paroma plays all these roles without demur, almost happily, Rahul's assistant, a white woman, raises an important question: she wonders how many names this woman actually has. For, she hears people calling her various names - kakima, pishima, boudi. While the family is humoured by a foreign woman's inability to make sense of kinship identities in India, the query sets the tone for the rest of the film - Paroma's quest to free herself from these several filial strings binding her to subservient roles as wife, daughter-in-law and mother, and to look for her own identity. Things change when Rahul enters her life and after a torrid affair their love story is discovered when an image of hers published in a magazine is emblazoned with Rahul's fond remembrance of their love. It changes Paroma's life; ostracized by her family she attempts to take her life. Sen's radicalism is palpable by the way in which she conflates Paroma's sexual awakening with her realisation of its vital link with economic independence. The security of the family is shown to rob Paroma of her own agency and as her daughter recalls in the early part of the film, Paroma (and by extension all Bengali women) is living her life only as a reflection of her husband. Within this heteronormative patriarchal structure she is positioned in the role of caregiver, as kakima (aunt), boudi (sister-in-law) or maa (mother), but in the midst of all these identities she loses her own. A contrast to Paroma is her friend Sheila (played by Sen herself). An expert homemaker, an outstanding cook and embroiderer, Sheila initially disconcerts Paroma for divorcing her husband. Paroma's daughter castigates her mother for being judgemental of her friend's priority of running her school for spastic children over relocating to Bombay with her husband and saving her marriage. Sheila disturbingly haunts the fringes of Paroma's happy household, dominated by a patriarchal husband and a stringent but patronising mother-in-law. Although Paroma is con- stantly ill at ease with Sheila's decision to leave her husband, she cannot give up on their friendship. As Paroma slowly discovers the joy of breaking free of moral codes handcuffing her to the filial roles of wife, mother, daughter-in-law, she can only confide in Sheila the sense of liberty her furtive love affair with Rahul has brought her. She knows Sheila is the least judge- mental of all her acquaintances, friends or family, and, gradually evolves to appreciate the latter's

notions of freedom and confinement.

Till date Paroma remains an iconic film that unsettled not only men but also women, in its bold declaration of the necessity for women to have the right to their own bodies and the freedom 
to make sexual choices. Herein, whilst Sen's cinema carried an unmistakable influence of Ray in style and treatment, thematically, she broke away from her mentor. Unlike Ray, whose treatment of women and their extramarital affairs in films such as Charulata/The Lonely Wife (1964), GhareBaire/The Home and the World (1984) and Pikoo (1980) was rather more moralistic and even conservative in resolution, Sen continued to lend voice to repressed women, assuming an almost iconic status for her portrayals. An incident that Sen mentioned to us needs to be cited to make sense of the power she has all along handed to women: 'At the premiere of Paroma, at the Indira theatre in South Calcutta, when I had several men waiting to protest against the film's celebration of a woman's adultery, three elderly women came up to me in confidence to thank me'. ${ }^{45}$ Later, alarmed by the reaction of the public, when her colleagues Dipankar De and Dilip Roy urged her to edit the film in a certain way to allay its radicalism, Sen did not pay them heed. The film made her an icon for championing women's causes, leading the prestigious Anandabazar Patrika group launched Sananda, till date the most popular Bengali women's magazine, with Sen as editor. ${ }^{46}$ In 1987, she was awarded the Padma Shri, the fourth highest civilian honour in India. In later films too, her feminist politics found expression in remarkable ways, as in the exploration of female bonding in Paromitar Ekdin, The Japanese Wife (2010) and Goynar Baksho. In fact Rituparno Ghosh, whose films Unishey April/April 19 (1995) and Dahan/ Crossfire(1997) are also regarded as landmark films pushing feminist politics can be traced back to Sen's influence, and Srimati Mukherjee writing about Dahan explains 'Ghosh had a context to draw from ... specifically films such as Paroma'. ${ }^{47}$ Mukherjee calls Paroma a 'feminist reform genre film', wherein Sen foregrounds not only Paroma's female sexuality but also her individuality and agency. In the next section, we move on from Sen's work as a film-maker to her career as an actor and the ways in which it shaped her stardom.

\section{The 'intelligent' actor with a radical edge}

As an actor, Aparna Sen has had an extremely long career: from her debut in Samapti in 1961 to playing a star film-maker in Srijit Mukherjee's thriller Chotushkone/Quadrangle in 2014, Sen has never been out of business as an actor. She has never been relegated to character roles, ${ }^{48}$ and has often shouldered films alone, without the support of any major male star. Although in recent years she has become extremely selective about acting in films, if she happens to appear in one, it is usually in a meaningful role, central to the plot. That she still commands this position in the Bengali film industry indicates her never-waning stardom; no other actor, her contemporaries or her juniors, male or female, could rival the kind of star power she wields. She is the only actorfilm-maker based out of Tollygunje to appear in Rendezvous with Simi Garewal, an immensely popular talk show on Star World, which has featured international icons from the world of cinema and sports along with celebrated business tycoons. Remarkably glamorous and agile even at 71, Sen is still acting and directing films; her latest film Arshinagar/The City of Mirrors (2015), though a commercial debacle, drew critical acclaim from the likes of the veteran academic Partha Chatterjee. $^{49}$ Sen told us, with a sense of pride, that the deal-breaker with the producer for her next directorial venture was the condition that she would have to act in it along with her other female lead Shabana Azmi. In an interview with The Telegraph, just before the release of Chotuskone, Sen, while explaining her character Trina, partly based on her own persona, said:

Somehow, both he [Srijit Mukherjee, the director] and Pupu [Parambrata Chatterjee, her co-actor] think of me as a diva. I can't imagine why, because I don't act like one in real life! So Trina, too, is a kind of diva in the film. ${ }^{50}$

Despite her modest dismissal of how her younger colleagues perceive her, Aparna Sen indubitably remains a diva even at 71 . Her radicalism which has always been ahead of its time, in any case, attributed to her a stardom, which no other Bengali female actor could claim. But, the fact that she has constantly changed with changing times accounts for her abiding appeal over half 
a century: she appears equally modern as Monica in Mrinal Sen's 1965 film Akash Kusum/ Woolgathering as in Rituparno Ghosh's Unishey April/April 19 as Sarojini in 1994. She has remarkably kept up with the times.

Sen's dominant image has been that of an English educated, metropolitan Bengali woman, elegant and sophisticated with a recognisable intelligence that animates her eyes and her body language. Although Sen (then, Dasgupta) made her debut as a village girl, in a classic 'taming of the shrew' narrative in Ray's Samapti, in later films, Sen was rarely ever seen essaying non-urban characters. The real-life Aparna Sen, and the screen life she often portrayed in the late 1960s and through the 1970s, the so-called golden period of Bengali cinema, has an interesting screen parallel in Ray's Pratidwandi/The Adversary (1970). A frustrated and unemployed Siddhartha, smarting from a terrible crisis-in-masculinity when his sister Sutapa secures a job, tells Shiben: 'These days the weaker sex is the stronger sex! Haven't you noticed how confidently they walk?' Shiben admits that they give him an inferiority complex. Before making this observation about the unprecedented empowerment of the 'weaker sex', Siddhartha insinuates the possibility of his sister using her sexuality to find employment. Notwithstanding whether Sutapa had indeed seduced her employer, the fact that the educated, metropolitan Bengali woman was powerfully and conspicuously present in the public domain, at times, jolting men out of their complacency as the rightful 'stronger sex', was brilliantly captured in Pratidwandi. Aparna Sen came to represent this new breed of the emancipated metropolitan women - 'out there', confident and articulate. ${ }^{51}$

The 1970s saw the emergence of a self-conscious feminist movement in India, which gathered an exceptional political momentum in different levels of society. "The "new feminism" which developed in North America and Europe (which also saw the 1970s being declared the decade of women)', observes Samita Sen, brought about this dramatic turn. ${ }^{52}$ The growing visibility of women of different social classes and urban as well as rural in the public domain, demanding their rights, protesting against patriarchal oppression and articulating their misgivings, also found expression in Bengali cinema. Although the radical political edge of the second-wave feminist movement was missing in these films, there was an unmistakable recognition of women's growing sense of independence. The recurrent appearance of urban working women as female protagonists in popular as well as art-house films of these years bears testimony to Bengali cinema's growing awareness of the new woman's question. Among the several films in which Aparna Sen played this new woman was Memsaheb (Dir: Pinaki Mukherjee, 1972) in which she was cast opposite matinee idol Uttam Kumar.

Belonging to an educated middle-class family of Calcutta, Kajal (also known as Memsaheb) falls in love with a journalist, in the backdrop of the Bangladesh Liberation War of 1971. The film charts the journey of Kajal from a college-going woman, financially dependent on a conservative uncle, to an emancipated professor who loses her life in a political agitation in her college, an incident not uncommon in the 1970s. In her journey, Kajal also assists the hero in finding his true calling, coaching him as a mentor. The film gradually builds Kajal's character, carefully locating her within a Bengali high culture - a student of history, she sings Tagore's songs, visits Tagore's Shantiniketan during the Spring Festival, takes time out to visit art exhibitions and libraries, urges the clueless hero to improve himself by reading the classics and buys him Tagore's Gitabitan, along with the works of Dorothy Parker, Ezra Pound, Aldous Huxley and Ernest Hemmingway to expand his intellectual horizon. At the same time, she rebels against the establishment - symbolized by her authoritarian uncle - by refusing to concede to an arranged marriage. Even in the 1970s, women choosing their own partners was often frowned upon by society; and Kajal, like her several counterparts in Bengali cinema of those times, rebels for love.

Mostly clad in handloom or silk saris, accessorized with minimalist but tasteful jewellery, Kajal speaks an urbane diction, an erudite Bengali, with a bit of English words thrown in, in her everyday conversations. At the same time, she acts effectively coy in the romantic scenes with the hero, subtly playing up her sensuousness in her gait, dialogue delivery and her overall body language. No other actor of her times, based out of Tollygunje, could have convincingly essayed 
this role, as Sen did; she was, actually, extending her real-life persona to the fictional Kajal, in the process, constructing for the masses a desirable image of the post-independence urban Bengali woman, who could spontaneously combine the sensuous with the cerebral. In a recent interview, her colleague Dipankar De, who has also been a close friend, talks about this uniqueness in her 'It has been a pleasure working with her. Because, in comparison to her, I found all my other female co-stars rustic - Sandhya Roy, Sumitra (Mukherjee) ... there was a recognisable urbaneness in her acting'. 53

In the 1960s and 1970s, in films as aesthetically diverse as Akash Kusum, Basanta Bilaap/The Protestations of Spring (Dir. Dinen Gupta, 1973), Raater Rajanigandha/The Tuberose of the Night (Dir. Ajit Ganguly 1973), Chhutir Phande/In the Trap of a Holiday (Dir. Salil Sen, 1974), Proxy (Dir. Dinen Gupta, 1977) and several others, Aparna Sen was seen in similar avatars - a sophisticated, sometimes rather westernized, woman, if not too radical. In a comic song sequence in Basanta Bilaap, in which she plays a working woman with a formidable personality, she dresses up in a short sleeveless top and pantaloons, smokes a cigar and dons large shades while lipsyncing a peppy number which mixes several genres of music: 'Ami Miss Calcutta 1976' (I am Miss Calcutta 1976). This song, which became immensely popular, begins on the fast beats of 'rock and roll', but, moves on to folk tunes from various regions of India, with each of the other three female leads performing a regional dance as the tunes change. This song, in which Sen imitates twist moves, as opposed to her colleagues who perform more traditional Indian dances, in retrospection appears symbolic of Sen's image within the Bengali film industry - the more westernized, the more metropolitan, English speaking actor, who was of a different breed compared with her more localized and demure contemporaries.

At this juncture, one is however, invariably reminded of one of Sen's contemporaries with whom she could be compared - Sharmila Tagore, an actor with whom she had many things in common. Both Sen and Tagore, coming of culturally upscale Brahmo families, were 'discovered' and introduced to the world of cinema by Ray, though the latter soon moved out of Tollygunje to discover phenomenal stardom in Bombay. In fact, the several characters rendered by Tagore in Ray's films epitomized the modern Bengali woman, the kind Aparna Sen also impersonated onscreen. Tagore's characters in films such as, Nayak/The Hero (1966), Aranyer Din Raatri/Night and Day in the Forest (1970) and Seemabaddha/Company Limited (1971) have interesting parallels with the characters played by Sen in the mainstream films discussed above. Suave, sophisticated and sensuous, both Sen and Tagore replicated on-screen their real-life personae, while producing an image which was widely idolized. However, despite Tagore'bslood relations with the venerable Tagore family of Jorashanko, through both her parents, she increasingly became distant to the Bengali culture, notwithstanding the fact that Ray often cast her, and she compromised her Bombay projects so as not to fail him. She forced director Shakti Samanta to shoot her scenes indoors for the iconic song in Aradhana/Worship (1969), 'Mere swapno ki rani kab aayegi tu' (When will you come, my dream queen?), a song set in the hills, ${ }^{54}$ as she could not refuse Ray's Aranyer Din Ratri, the shoot of which coincided with Aradhana, which incidentally became one of her biggest commercial successes ever.

Sen and Tagore, however, have had very different career trajectories, owing to Tagore's foray into Hindi films with the hugely successful Kashmir Ki Kali/The Flower of Kashmir (Dir: Shakti Samanta, 1964) after which she returned to Kolkata mostly to act in Ray's films. She was not seen in commercial Bengali cinema till the mid-1980s, ${ }^{55}$ when film-makers often turned to Bombay, desperately looking for stars to compensate for the huge vacuum created by the sudden demise of Uttam Kumar in 1980. While Aparna Sen emerged as a radical film-maker, challenging normative assumptions about women, sexualities and conventional moralities, Sharmila Tagore rarely broke the mould of the stereotypical romantic heroine, submissive, coy, sacrificing and moralistic, with a few exceptions. ${ }^{56}$ Yet, she broke the mould in other ways: she insisted on sporting the bikini in $A n$ Evening in Paris (Dir: Shakti Samanta, 1967) to which Samanta reluctantly agreed, ${ }^{57}$ fearing the Indian censorship's moralistic standpoint about inappropriate clothes. Tagore made headlines and 
cover stories in the late 1960s, post her bikini act in this tremendously successful film. The 19 August 1968 issue of Filmfare magazine had a sizzling Tagore in a printed two-piece bikini on its cover, and carried several such pictures, in one of the most sensational photo shoot features of those times. She married Nawab Mansoor Ali Khan Pataudi at the height of her stardom in 1969, converted to Islam and continued to work in films as the female lead, although in those times a female actor's career usually ended with marriage. However, Tagore's radicalism was to a great extent whitewashed by her co-option into the feudal life of opulent nobility, and more importantly, her uncritical association with commercial cinema and the glamour industry. It is in recent times that Tagore has emerged as a more culturally aware socialite who is often seen at literary and cultural events, talking about books and films, and giving cerebral interviews about women's liberation, the importance of women's economic independence and other social matters. This was certainly not the image Tagore projected while at the helm of success.

Aparna Sen, on the other hand, especially, after the release of her directorial debut 36, Chowringhee Lane, began consciously projecting and cultivating the image of a sexually liberated, educated modern woman who effortlessly participated in intellectual debates, analysed the political environment of the country, and meaningfully contributed to the progress of the women's movement through her writings and cinema. Sen's intellectualism, liberal ideas and measured coyness which she very consciously performed both off- and onscreen were deeply rooted in a Bengali bhadrolok culture. She was desirable, but not completely inaccessible. As editor of a bimonthly women's magazine, as a film-maker and a cultural commentator, Sen has always been more visible within the public sphere, and therefore, more reachable, at least theoretically. This is precisely where her stardom differs from Tagore's, whose overwhelming glamour, repeated pairing with national screen idols such as Shammi Kapoor, Rajesh Khanna, Dharmendra and others, and most importantly her marriage into a revered royal family, made her far less reachable. In the public imagination, Tagore has always remained the glamorous star of Bombay films, who had a fairy tale marriage with a prince and lived in unimaginable plenitude, a lifestyle with which the average Indian could barely identify. In comparison, Sen, owing to her writings, her romantic liaisons and marriage with identifiable men, and her familiarity with middle-class life, which her films also mirrored, has always appeared more real, closer to earth and therefore, not completely wrapped in the halo of an unattainable, fantastical stardom.

In fact, whether in commercial or art-house cinema, unlike Tagore, Sen has constantly made conscious efforts to break away from submissive, law-abiding, conformist characters that A-list female actors played, and often preferred to portray in films the 'other woman', Kalankita Nayak/ The Blemished Hero (Dir. Salil Dutta, 1970), Asati/The Unfaithful Wife (Dir. Salil Dutta, 1974) and Mohanar Dikey/Towards the Confluence (Dir. Biresh Chatterjee, 1984) being a few examples. In the interview with us, Sen said playing decorous heroines was boring; these roles, she rued, had no challenge in them, for they only expected the female actor to convincingly perform coyness with a certain degree of affectation. In Mohanar Dikey, she convinced the Director Biresh Chatterjee to cast her as the seductress, although the director wanted her as the female lead victimized by her husband's adulterous liaison with the other woman. The role of the other woman was risqué, and, initially the sympathy of the film-maker lay completely with the unsuspecting and faithful wife. In fact, the other woman's character did not even have much screen time. But later, when Sen showed interest in the character, the director saw the character writing itself into the script, evolving and expanding its own screen time, marginalizing the modest female lead. The focus of the film eventually shifted from the latter to the other woman, although the ending, conforming to the demands of commercial cinema, rescues her from the path of $\sin$.

In 1984, Satyajit Ray also cast Senas an adulterous wife in his telefilm made for French television, Pikoo. It was a risk very few mainstream female actors of that time would have agreed to take in the apprehension of alienating Indian audiences who, in those days, had stubborn 
reservations about the heroine transgressing moral codes. Sen had no diffidence about such a role, although it was written in a way that could invite strong moral judgement from the audience. However, she did question Ray about the character's predicament, as she told us. She could not accept the fact the character was being held responsible for cheating on her son and her father-inlaw, besides, her husband, for having an extramarital liaison with another man. She could not understand why she was reproached for cheating on every family member, when the only person who could 'legitimately' feel betrayed by her was her husband. Although she does not agree with us, we believe that her second film Paroma which was released within 4 years of Pikoo's premier on French television was a bold feminist rejoinder to Ray's more conservative Pikoo.

In her later films, Sen, who has evolved with changing times, continued to play emancipated, urban characters, often breaking stereotypes and emerging iconic in her dignified rebellion against patriarchal norms. One such film is Rituparno Ghosh's Unishey April which dramatized a widowed dancer's difficult relationship with her daughter, who fails to empathize with her mother's uncompromising pursuit of her career, and apparent neglect of her household. Sarojini persuasively brings out the dilemmas of the married working woman, ${ }^{58}$ torn between home and her professional calling. Without choosing one over the other, she emphasizes the importance of both - for both are key to shaping a woman's identity. Ghosh also de-familiarized the image of the Bengali widow considerably: liberating her from patriarchal constrictions which expect her to conform to certain codes of behaviour and embrace an asexual life, he had Sarojini have a lover in Somnath who she does not marry. The film ends with the estranged daughter returning to her mother who she has all along misunderstood, but not before Ghosh had convincingly dismantled the stereotypical mother figure. Unishey April overturned the moral registers of filial relationships, by locating them within liberal feminist discourses. It is essential to note here that it was Aparna Sen's stardom that actually made Sarojini convincing - the star dancer who does not have enough time for domestic responsibilities. Ghosh, who had actually asked Sen to decorate Sarojini's room according to her taste, ${ }^{59}$ consciously effectuated this overlap - Aparna Sen, the star and a mother of two daughters, effortlessly fit into Sarojini's role with all her dilemmas and trepidations. Ghosh, who was a very close friend of Sen, also wrote into the script exchanges Sen had with her own daughters at home, and to which he was privy. ${ }^{60}$ Another film which needs to be examined in this context is Paromita'r Ekdin in which Sen played Sanaka, an ageing middle-class housewife of a traditional north Kolkata family. Though formally uneducated, Sanaka, the character Sen essayed, is sharp, witty and unexpectedly liberal. Saddled with unending domestic chores which include rigorous caregiving to a schizophrenic daughter and meeting the demands of a chauvinistic husband, Sanaka grows cantankerous and irritable, until she develops a deep bonding with her daughter-in-law, after her husband's demise. In a long time, Sen broke the mould of the stereotype of the English-educated refined metropolitan woman, a role in which she has been repeatedly cast. The film took Sen's feminist agenda a step further, by introducing an ambiguity in the nature of relationship between Sanaka and Paromita, her daughter-in-law - undercurrents of homoeroticism are present in several scenes. The film, released 2 years after Deepa Mehta's highly eristic Fire, accommodated female homoeroticism within a middle-class Bengali household, without causing discomfort to its more conservative audience. Though touched by the exceptional camaraderie between mother-in-law and daughter-in-law, a rare treat in Bengali cinema, a less alert viewer missed the homoerotic undertone in the relationship, which manifested itself in unremarkable activities, such as bathing, skincare regimes, tying each other's hair or even in reading poetry together. Sen did not allow the homoeroticism to stand out; rather she channelized it into the everydayness of the relationship, while making an extremely powerful point about female bonding.

Sen's popularity, her image as a cerebral, emancipated woman, and her dedication to her art are evident in the way she is adored by her colleagues. In Rendezvous with Simi Garewal, Simi quotes Shabana Azmi as claiming: "Aparna is singularly the most intelligent woman that I know'. ${ }^{61}$ On the sets of Aparna Sen's underproduction film Sonata, when we met Shabana 
Azmi, she reiterated the claim, adding that she was so deeply impressed with 36 Chowringhee Lane, that she wrote a letter to Sen to cast her in Sati (1989). Rahul Bose, who has acted in three of Sen's films, calls her 'PD, short for prima donna, because of the way she is worshipped in Bengal'. ${ }^{62}$ When Rituparno Ghosh was asked which female personality 'represented desirable femininity' to him in his formative years, his unequivocal reply was: 'Aparna Sen!' His interviewer, the queer film critic and academic, Shohini Ghosh added to that: 'I like to say that I grew up desiring Aparna Sen and Ritu grew up desiring to be her' ${ }^{63}$ This statement deserves a closer scrutiny for it hints towards something very interesting: while establishing Sen as sexually desirable, it also underlines the fact that, owing to her radicalism, she also became a queer icon for an earlier generation for which there was no queer model to look up to. In an interview with Kaustav Bakshi, Rituparno Ghosh made an interesting observation. Referring to Sen's declaration in the press that she wanted legal separation from her husband, Ghosh observed: 'At that time divorce was a social stigma for a woman .... There used to be endless moralizing about these things. But the times have changed ... a woman seeking divorce is no longer stigmatised'. ${ }^{64}$ The point which Ghosh was trying to make is that, remaining within heterosexual frameworks of marriage and relationships, Sen, who constantly challenged and dismantled norms, opened up the possibility of more radical sexual choices to articulate themselves: ' $\ldots$ a time will come when non-normative sexualities would also be recognized, and social resistance towards it would dwindle', speculated an optimistic Ghosh. ${ }^{65}$ It is certainly not in the power of the star to influence how her stardom is perceived or the ways in which it influences people's lives. But, the fact that stars do influence people in strange and often unforeseen ways is the hallmark of stardom itself. Ghosh's perception of Aparna Sen hints at the extraordinary power a star possesses - a power that can transform lives.

\section{Coda}

In this paper, we have attempted to trace Aparna Sen's stardom through an exploration of her role as a cultural commentator, a conscientious feminist, film-maker and actor. Although Sen's films, cultural commentary and issue-based politics are firmly located within a Bengali bourgeois consciousness, their political dimension, though not too disruptive, is manifested in their engagement with the discourses of modernity - a disidentification with the idea of nationalist idealism, a distrust for the nationalist project of the woman's question, an apprehension of the increasing fractures and conflicts across ethnic lines and a growing concern with the banes of modernity, the social, moral and environmental degeneration wrought by war and technological progress.

Sen's stardom subverts and complicates the nature of star culture and celebrity texts in India. Sen introduced a powerful feminist voice in an industry dominated by male film-makers. Her feminist politics were couched in narratives surrounding middle-class households and proved unsettling for many unused to explicit representations of female desires on-screen. The anti-patriarchal discourses her films inaugurated won Sen many accolades, and worked towards consolidating her stardom as a film-maker in the Bengali/Indian film industry. Her issue-based intervention in politics and social activism through her editorial columns in Sananda to street protests in 2009 on the issue of Nandigram firmly positioned her as the 'radical humanist' that she believes herself to be. Sen's stardom was, therefore, not confined only to the films she acted in or directed but was also constructed by a cultural activism that manifested itself beyond the celluloid. This creativity, transgression and art make the complex symphony of Sen's stardom.

\section{Notes}

1. Aparna Sen has been a constant presence in international film festivals since 1976 when she served on the jury in the Sixth International Film Festival in India (which was chaired at that time by Satyajit Ray) followed 
by the Moscow Film Festival in 1989. Her films have also been part of retrospectives at the National Theatre and the Institute for Contemporary Arts, both in London. She is also the third Indian since Satyajit Ray and Mrinal Sen to have won the Netpac Jury Award at the Locarno Film Festival in 2002 (Also see Chatterji, Parama and Other Outsiders).

2. For example, Datta, Bakshi and Dasgupta, Rituparno Ghosh; Dwyer, Yash Chopra and Kabir, Guru Dutt.

3. See Lewis, "Cool Postfeminism," 176.

4. Apart from Paranjpye, none of them, however, have produced any considerable body of work.

5. Gooptu, Bengali Cinema, 3.

6. She touched upon this in her representation of the protagonist in Iti Mrinalini, partly modelled on her own life.

7. Personal interview with Aparna Sen, 17 August 2015.

8. As an example, one may cite her vociferous protest against the Left Front led West Bengal Government's neoliberal industrialisation policies in Nandigram which caused several farmers to give up their farming land. Her involvement was welcomed by activists not just for lending her name to a worthy political cause but also for standing up to her beliefs despite coming from a family of Left supporters and being a supporter of the Left Front government in West Bengal.

9. Dyer, Stars, 34 .

10. See Marshall, Celebrity and Power.

11. Dudrah, Mader and Fuchs, "Introduction".

12. See Bhusan, "Controversy-ridden year for soft drinks".

13. See note above.

14. The Sharadha financial scam brought to the fore the names of several ministers of the ruling Trinamul Congress for their alleged involvement in shady financial transactions, in one of the biggest scams in the country. Commonly referred to as chit funds, the Sharadha group was a consortium of 200 companies that ran investment schemes, which had become tremendously popular at the grassroots level. The company collapsed in April 2013 leading to the suicides of many investors, the arrest of Trinamul Congress ministers and the revelation of several public personalities for their alleged role in the scam.

15. On 7 June 2013, nine men gang raped and tore apart a 20-year-old girl's legs up to the navel and slit her throat before dumping the body in a fish pond in West Bengal's North 24-Parganas district. See, Bhabini 2016.

16. See, Aparna Sen's interview with Maya Mirchandani on NDTV, published on 22 August 2014.

17. Benjamin, "The Work of Art in the Age of Mechanical Reproduction," 231.

18. Taylor, “"Baby I'm a Star”," 158.

19. Iti Mrinalini traces the life of a female Bengali film star of the 1970 s, her career and her many relationships. The film is partly autobiographical.

20. Ghosh, "Books she likes, films she loves".

21. Sengupta, "Director's Special".

22. Brahmoism, as opposed to Hinduism, is a monotheistic religion and was one of the most influential religious movements in India. Brahmoism contributed to the making of modern India in a significant way. It was started in Calcutta on 20 August 1828 by Raja Ram Mohan Roy and Debendranath Tagore as a reformation of conservative Brahmanism of the times. This also marked a significant move in inaugurating that which later came to be known as the Bengal Renaissance. The first Brahmo Samaj - a societal component of Brahmoism - was founded in 1861 at Lahore by Pandit Nobin Chandra Roy. It became a phenomenon in late nineteenth-century Calcutta, with several important personalities of Bengal converting to Brahmoism.

23. See note above.

24. Ibid., 7-8.

25. Ridms sOtheir Films

26. As Sen told the authors in their interview, Pather Panchali was the first Bengali film she ever saw.

27. Dasgupta, The Cinema of Satyajit Ray, 32.

28. Sen, Interview with Sandip Ray. Aparna Sen Blog. 13 July 2009. http://aparnasen.blogspot.in/.

29. Biswas, Apu and After, 2

30. See note above.

31. Sengupta, "Words and Images".

32. The opening line translates as 'O those overwhelmingly mighty waves!' The song from Tagore's Gitabitan, while celebrating the immensity and infinity of the universe, extols life itself, the human consciousness merging into the indefinable universe.

33. Apart from James Ivory's Shakespeare wallah (1965) with which Satyajit Ray was associated as music composer, there were no Indian films at that time that meaningfully and sensitively portrayed the AngloIndian community.

34. Chowdhury, "Unveiling the Anthropo(s)cene," 219. 
35. Paroma, as Sen ,hared with us, despite the criticisms it received from the conservative middle classes, ran uninterruptedly for 17 weeks, in theatres that usually screened only popular films.

36. Dasgupta, “Aparna Sen Calls the Shots," 15.

37. Personal interview with the authors, 30 October 2016.

38. Personal interview with the authors, 2 November 2016.

39. Personal interview with the authors, 29 October 2016.

40. Personal interview with the authors, 6 November 2016.

41. See note above.

42. Narayanan, "36 Chowringhee Lane," 181.

43. Staheli and Martin "Spaces for Feminism".

44. Pan Bamótou,Ekdin and Goynar Baksho, the chhad (terrace) and the chhader-ghar (the room on the roof) have significant metaphorical currency, related to the ideas of liberation and incarceration of women within middle-class Bengali homes.

45. Personal interview with Aparna Sen, 30 August 2015.

46. Sen edited Sananda for 20 years, till 2005.

47. Mukherjee, Women and Resistance, 47

48. In Indian cinema, 'character role' signifies the supporting cast, other than the protagonists.

49. Chatterjee, "A different future".

50. Sengupta, "Aparna the Actress".

51. Gooptu in her book also mentions in passing how Sen epitomized a modernity which set her apart from her female co-stars, 262.

52. Sen, "Towards a Feminist Politics,"24.

53. Bhattacharya, "I fell out with Uttam Kumar at the time of acting in Banchharamer Bagan".

54. "Canehishtion with Sharmila Tagore," DD News.

55. In the 1970s, she appeared in two bilingual films with Uttam Kumar, Amanush/The Inhuman (1975) and Ananda Ashram/The Retreat of Joy (1977), both directed by Shakti Samanta. She was suddenly more visible in Tollygunje in the 1980s, beginning with Kalankini Konkaboti/The Stigmatised Konkaboti (1981), also one of the last films of Uttam Kumar, and released posthumously. In Bombay, Tagore began to be cast in character roles from the mid-1980s onwards, whereas in Tollygunje, she was still the leading lady perhaps that was one reason why she did more films in Bengali at that time.

56. A few films such later films are Satyakam/The Desire for Truth (1969) directed by Hrishikesh Mukherjee, Mausam/Season (1975) and Namkeen/The Salty (1982), both directed by Gulzar. Although Tagore was appreciated critically for her performance in all three films mentioned above, none of the characters she essayed were remarkably radical.

57. "IsiekeanaNam Hain - Sharmila Tagore," Episode 24, Zee TV.

58. In an early issue of the magazine Sananda (15 June 1989), Sen explored the plight of 'ekalermeye' (the modern woman), that Sarojini epitomizes in the film, and the discrimination that these women faced within their own families and in the course of their working careers.

59. Personal interview with Aparna Sen, 5 October 2015.

60. Sen, 262

61. Rendezvous with Simi Garewal: Aparna Sen E Konkana Sen (2003).

62. Quoted in Dasgupta, "Aparna Sen Calls the Shots," 31.

63. Ghosh, "Shohini Ghosh in Conversation," 237.

64. Bakshi, "Kaustav Bakshi in Conversation," 247-248.

65. Dltidi.

\section{Disclosure statement}

QQ5 No potential conflict of interest was reported by the author.

\section{Bibliography}

Bakshi, K. "Kaustav Bakshi in conversation with Rituparno Ghosh." In Rituparno Ghosh: Cinema, Gender and Art, edited by S. Datta, K. Bakshi, and R. K. Dasgupta, 240-248. New Delhi: Routledge, 2015.

Bhabini, S. 2013. "Kamduni victim's kin want death for rapists". June 7. http://indiatoday.intoday.in/story/westbengal-kamduni-victims-kin-want-death-for-rapists/1/582405.html

Benjamin, W. "The Work of Art in the Age of Mechanical Reproduction." In Illuminations: Essays and Reflections, edited by H. Arendt, 217-252. New York: Schocken Books, 1969, 1936. 
Bhattacharya, S. 2016. I fell out with Uttam Kumar at the time of acting in Banchharamer Bagan: Interview with Dipankar De. Partika, 12 March.

Bhushan, R. 2003. "Controversy-ridden year for soft drinks". Business Line: Internet Edition, December 30. http:// www.thehindubusinessline.com/bline/2003/12/30/stories/2003123000460600.htm

Biswas, M. "Introduction: Critical Returns." In Apu and After: Revisiting Ray's Cinema, edited by M. Biswas, 1-19. London, New York and Calcutta: Seagull, 2005.

"Candid Conversation with Sharmila Tagore". DD News. Accessed December 10, 2016. https://www.youtube.com/ watch? $=$ mELUYzXBO-M

Chatterjee, P. 2015. "A different future: Aparna Sen's innovative adaptation of Romeo and Juliet." The Telegraph, December 31. http://www.telegraphindia.com/1151231/jsp/opinion/story_61312.jsp\#.VoX-yLZ97IV

Chatterji, S. Parama and Other Outsiders: The Cinema of Aparna Sen. Kolkata: Parumita Publications, 2002.

Chowdhury, S. "Unveiling the Anthropo(s)cene: Burning Seas, Cinema of Mourning and the Globalisation of Apocalypse." In Sea Narratives: Cultural Responses to the Sea, 1600-Present, edited by C. Mathieson, 217-238. 2016. doi:10.1057/978-1-137-58116-7_9.

Dasgupta, C. The Cinema of Satyajit Ray. Kolkata: National Book Trust, 1992.

Dasgupta, R. "AparnaSen Calls the Shots." In Women in Indian Film, edited by N. M. Kabir. New Delhi: Zubaan, 2008.

Datta, S., K. Bakshi, and R. K. Dasgupta. Rituparno Ghosh: Cinema, Gender and Art. London: Routledge, 2015.

Datta, S. Interview with Aparna Sen. In Rituparno Ghosh: Cinema, Gender and Art, edited by S. Datta, K. Bakshi, and R. K. Dasgupta. 260-264. New Delhi: Routledge, 2015.

Dudrah, R., E. Mader, and B. Fuchs. "Introduction." In SRK and Global Bollywood, edited by R. Dudrah, E. Mader, and B. Fuchs, xi-xxxviii. New Delhi: Oxford University Press, 2015.

Dwyer, R. Yash Chopra (World Directors). London: British Film Institute, 2002.

Dyer, R. Stars. London: British Film Institute, 1979.

Ghosh, R. 2013. "Books she likes, films she loves: Interview with Aparna Sen". The Telegraph: t2, September 19. http://www.telegraphindia.com/1130919/jsp/t2/story_17365090.jsp\#.V-PxXoh97IW

Ghosh, S. "Shohini Ghosh in conversation with Rituparno Ghosh." In Rituparno Ghosh: Cinema, Gender and Art, edited by S. Datta, K. Bakshi, and R. K. Dasgupta, 227-239. New Delhi: Routledge, 2015.

Gooptu, S. Bengali Cinema: An Other Nation. London: Routledge, 2011.

Jeena Isi Ka Naam Hain: Sharmila Tagore. 1999. Episode 24. Zee TV. April 11. Accessed December 10, 2016. https://www.youtube.com/watch?v=Oy9ZbiwiJRk\&t=2412s

Kabir, N. M. Guru Dutt: A Life in Cinema. New Delhi: Oxford University Press, 2004.

Lewis, C. Y. "Cool Postfeminism: The Stardom of Sofia Coppola." In In the Limelight and Under the Microscope: Forms and Functions of Female Celebrity, edited by S. Holmes and D. Negra. London: Bloomsbury, 2011.

Marshall, D. Celebrity and Power: Fame in Contemporary Culture. Minneapolis: University of Minnesota Press, 1997.

Mukherjee, S. Women and Resistance in Contemporary Bengali Cinema: A Freedom Incomplete. London: Routledge, 2016.

Narayanan, K. "36 Chowringhee Lane." In The Cinema of India, edited by L. Gopalan, 180-189. London: Wallflower, 2009.

Ray, S. Our Films, Their Films. New Delhi: Orient Blackswan, 1976. Reprint, 2015.

Rendezvous with Simi Garewal: Aparna Sen \& Konkana Sen. 2003. "Simi Garewal Official". Accessed March 24, 2014. https://www.youtube.com/watch?v=1kkOKmyld5k

Sengoopta, C. The Rays Before Satyajit: Creativity and Modernity in Colonial India. New Delhi: Oxford University Press, 2016.

Sengupta, R. 2013. “Director's Special: Rituparno Ghosh interviews Aparna Sen.” The Telegraph: t2, April 13. http:// www.telegraphindia.com/1130412/jsp/entertainment/story_16774443.jsp\#.V-PykYh97IW

Sengupta, R. 2014. "Words and Images: Interview with Aparna Sen and Kalyan Roy.” TheTelegraph: t2, July 24. http://www.telegraphindia.com/1140724/jsp/t2/story_18646387.jsp\#.V-P0XYh97IX

Sengupta, R. 2014. "Aparna the Actress." The Telegraph: t2, September 25. http://www.telegraphindia.com/1140925/ jsp/t2/story_18868530.jsp\#.V-P334h97IW

Sen, S. "Towards a Feminist Politics? The Indian Women's Movement in Historical Perspective1". Policy Research Report on Gender and Development: Working Paper Series no. 9. New York: The World Bank Development Research Group/Poverty Reduction and Economic Management, April, 2000.

Staheli, L., and P. Martin. "Spaces for Feminism in Geography." Annals 571, no. 1 (2000): 135-150.

Sen, A. 2014. "Aparna Sen on her role in Saradha". Interview with Maya Mirchandani, August 22. https://www. youtube.com/watch?v=DZPx8eR6k-8

Taylor, L. "“Baby I'm a Star": Towards a Political Economy of the Actor Formerly Known as Prince." In Film Stars: Hollywood and Beyond, edited by A. Willis, 158-173. Manchester and New York: Manchester University Press, 2004. 